\title{
EFL Classes Must Go Online! Teaching Activities and Challenges during COVID-19 Pandemic in Indonesia
}

\author{
Arief Eko Priyo Atmojo ${ }^{1^{*}}$, Arif Nugroho² \\ IAIN Surakarta, Indonesia ${ }^{12}$ \\ arief.atmojo93@gmail.com¹, arifnugroho.iainsurakarta@gmail.com² \\ ${ }^{*}$ Corresponding Author \\ DOI: https://doi.org/10.18326/rgt.v13i1.49-76
}

Submission Track:

Received: 28-04-2020

Final Revision: 28-05-2020

Available Online: 01-06-2020

\begin{abstract}
In view of the COVID-19 pandemic and government policy to carry out online learning, the present research is aimed at investigating how EFL teachers carry out online EFL learning and its challenges. 16 EFL teachers volunteered to participate in this research through invitation. The EFL teachers were requested to make written reflections regarding their practices in carrying out online EFL learning and the challenges they encounter. Five of them were involved in a follow-up interview individually. Semi-structured interview was administered. Data coding was done and appropriate extracts were informed in results section. To validate the data, data coding was done independently by
\end{abstract}


both researchers, continued by several cycles of discussion. As results, the EFL teachers have carried out online learning through a series of activities ranging from checking the students' attendance to giving score on the students' works synchronously or asynchronously depending on each school policy. Various applications and platforms ranging from learning management system to additional resource are employed. However, many problems emerge from the students, the teachers, and the students' parents along with the valid reasons. Therefore, the online learning does not run well since it lacks of preparation and planning. Implications for better online learning are discussed. Future prospective researches are directed and encouraged.

Keywords: COVID-19, EFL teachers, online EFL learning, technology enhanced language learning, technology in language learning.

\section{INTRODUCTION}

Coronavirus disease 2019 (COVID-19) originating from Hubei Province of the People's Republic of China has become a current pandemic over the world. Many countries have been affected by this virus. In late January 2020, a global health emergency state was announced by the WHO Emergency Committee as COVID-19 confirmed cases have been increasing internationally (McAleer, 2020; Velavan \& Meyer, 2020). COVID-19 has spread in all continents, but Antarctica as of 26 February 2020. Latest news on COVID-19 have overloaded worldwide mass media every day in 2020 (McAleer, 2020).

In 1 April 2020, the number of confirmed COVID-19 cases in Indonesia has reached more than 1.500 cases (WHO, 2020). The National Disaster Management Authority of Republic of Indonesia has decided to extend the period of disaster emergency caused by COVID-19 pandemic until 29 May 2020 (BNPB, 2020). The global spread of COVID-19 pandemic causes class suspensions resulting in the needs of online learning (Moorhouse, 2020). 
REGISTER JOURNAL

Vol. 13, No. 1, (2020), pp.49-76

p-ISSN: 1979-8903; e-ISSN : 2503-040X

Website: http://journalregister.iainsalatiga.ac.id/index.php/register/

The Minister of Education and Culture of Republic of Indonesia has instructed schools to carry out online learning since 17 March 2020 for COVID-19 affected areas (Mendikbud, 2020b). Soon after that, the Minister of Education and Culture of Republic of Indonesia has ordered all education units to run online learning from 24 March 2020 due to the increasing spread of COVID-19 and maintaining the health of students, teachers, and all educational staffs (Mendikbud, 2020a). These policies lead students to learn from home and teachers to work from home, too. It fully replaces face-to-face learning in classroom setting into online learning which possibly lasts till the end of semester due to the COVID-19 pandemic. It becomes a new challenge for both students and teachers to run online learning. According to Cao et al. (2020), these actions certainly give impact on education, particularly students' growth.

Online learning researches usually explore stand-alone online learning tools, instructional methodologies or techniques, unique environments within a blended learning program, and comparison between classroom-based and fully online learning. The emphasis is commonly on the students' attitude, perception, assessment, evaluation, satisfaction, and performance (Gonzalez \& Louis, 2018; Sun, 2014). Although a big number of research has been done quantitatively and qualitatively to investigate the effectiveness of online learning (Gonzalez \& Louis, 2018), a research on online language learning carried out during a pandemic is very rarely found, especially in English as Foreign Language (EFL) context in secondary school settings as most online language learning researches have been done in tertiary education level (Chin- 
Hsi Lin \& Warschauer, 2015). This pandemic causes the fully online language learning to occur in a sudden and completely unprepared situation. Whereas, a particular research investigating fully online language learning is very rare (Sun, 2014), especially during a pandemic.

English still becomes the most renowned foreign language in Indonesian schools. It remains as the first foreign language. It has been officially taught in Indonesian secondary schools since a long time ago (Jayanti \& Norahmi, 2014; Kam, 2002; Lie, 2007; Yusny, 2013). As a foreign language, English has gained a special status among other foreign languages existing in Indonesia because of many true causes (Lauder, 2008). Secondary school students are required to take this subject since it is compulsory throughout secondary schools in Indonesia. This subject is determined as essential among other subjects. Students are also required to take this subject in national examination (Jayanti \& Norahmi, 2014; Lie, 2007; Yusny, 2013; Zein, 2018). Almost $11,000,000$ students learn English in formal education every year and they are very diverse (Lie, 2007). Undoubtedly, Indonesia has become one of the most prospective markets to teach English (Zein, 2018).

In global context, English becomes a school subject and is required to own a bargain in job position. It occurs as high unemployment exists and English mastery is much appreciated in workplace, business, and tourism. It shows the economic benefits of mastering English to people (Jayanti \& Norahmi, 2014; Smith, 1991). Not surprisingly, the current issues and trends of English Language Teaching (ELT) are mainly concerned by education experts, pedagogical practitioners, language policy makers, and linguists (Jayanti \& Norahmi, 2014).

In lights of the importance of English in Indonesia and international world, the Ministry of Education and Culture issued a decree in 1967 
REGISTER JOURNAL

Vol. 13, No. 1, (2020), pp.49-76

p-ISSN: 1979-8903; e-ISSN : 2503-040X

Website: http://journalregister.iainsalatiga.ac.id/index.php/register/

explaining the functions and purposes of teaching English in secondary schools. English is believed to function in (1) accelerating national development since a great deal of modern science resources are only available in English; (2) creating relationships with other nations; and (3) implementing national foreign policy. Moreover, the purposes of teaching English in secondary schools are to equip students with the mastery of four English language skills such as reading textbooks, communicating with and learning from foreigners, and promoting Indonesian culture to other nations (Jayanti \& Norahmi, 2014; Smith, 1991).

Online learning goes on to spread internationally since students and teachers feel comfortable and see possibility in setting up and accessing opportunities to learn alternatively (White, 2008). Online learning means a set of learning activities in a subject delivered through network giving access and exchange of knowledge. This terminology has appeared specially to point out an approach of teaching and learning which involves internet technology. Online learning environment is not only useful for students to access knowledge and materials but also to associate and make collaboration among course participants (Krish, 2008). Online learning is also perceived as the utilization of internet in accessing materials; having interaction with contents, teachers, and other students; and gaining assistance in learning process to gain knowledge, make meaning, and progress through learning experience (Ally, 2008). Online learning is defined as learning carried out from a distance assisted by electronic devices, for instance tablets, smartphones, laptops, and computers which require internet connection (Gonzalez \& Louis, 2018). 
The widespread use of online learning inevitably brings students into alternative places for online language learning (Plaisance, 2018). Online language learning (OLL) may point various learning adjustments, namely a web-facilitated learning, a hybrid or blended learning, and a fully virtual or online learning. Moreover, the online language learning in EFL context in secondary school settings during the COVID-19 pandemic takes place in fully online language learning because students and teachers are not possible to gather in a face-to-face context (Blake, 2011).

In view of the COVID-19 pandemic and government policy to carry out online learning which causes students to learn from home and teachers to teach from home too, this research investigates how EFL teachers carry out online EFL learning and what challenges they deal with as well as valid reasons. Drawing on written reflections data from secondary school teachers from various cities in Indonesia, this research contributes to the realm of online language learning researches. It enriches the knowledge of how EFL secondary school teachers in Indonesia carry out online EFL learning in a sudden and completely unprepared situation due to the COVID-19 pandemic. It also sheds some lights on the challenges they encounter during their practices of carrying out online learning. Therefore, questions leading the present research are: (1) How do EFL teachers carry out online EFL learning during the COVID-19 pandemic? (2) What challenges do EFL teachers deal with in carrying out online EFL learning during the COVID-19 pandemic?

\section{RESEARCH METHOD}

\section{Research context and participants}

This research was carried out in Indonesia which ranks second in language diversity among other countries worldwide (Zein, 2018), where 
REGISTER JOURNAL

Vol. 13, No. 1, (2020), pp.49-76

p-ISSN: 1979-8903; e-ISSN : 2503-040X

Website: http://journalregister.iainsalatiga.ac.id/index.php/register/

English has been put into priority as the first foreign language and become compulsory for secondary school students (Jayanti \& Norahmi, 2014; Lie, 2007; Yusny, 2013; Zein, 2018). However, English is very rarely spoken in Indonesians social life. It is mostly used for academic, professional, and business purposes (Lie, 2007; Yusny, 2013).

Indonesian EFL teachers tend to use Indonesian for both written and oral communication purposes in academic forums (Lie, 2007) and classrooms (Marcellino, 2005). They do not keep their English proficiency after receiving formal teacher education and training. Their proficiency is possible to decrease as time goes by (Wulyani, Elgort, \& Coxhead, 2019). Not surprisingly, many Indonesian EFL teachers do not master the language they teach (Lie, 2007). English is determined as a foreign language in the present research (Wulyani et al., 2019).

The participants were 16 EFL teachers consisting of 12 females and 4 males from 11 different cities and 16 distinct secondary schools in Indonesia. All teachers owned a college degree to teach English as a foreign language. They had experience in teaching English as a foreign language which ranged from 1 to 18 years. Their mother tongue is their regional languages respectively. As a national language, Indonesian becomes their second language functioning for communicative purposes among people having distinct regional language and instructional media in schools and formal events (Lie, 2007). 


\section{Data collection and analysis}

16 EFL teachers (called as T1-T16) volunteered to become participants in this research through invitation. According to a list of questions, the EFL teachers were requested to make written reflections regarding their practices in carrying out online EFL learning and the challenges they encounter. Furthermore, five of them (i.e. T3, T7, T8, T9, and T10) were involved in a follow-up interview individually since they provided attractive narrations and impactful topics in the written reflections and were determined feasible to be investigated further. Semi-structured interviews were administered and took place about 30 minutes for every interviewee. The participants were asked to share detailed explanations on teaching procedures, online learning tools used, and samples of materials, quizzes, assignments, as well as projects given to the students to depict the practices of online EFL learning which they carried out during the COVID-19 pandemic as pointed out in the written reflections. The teachers were also led to discover the challenges they encountered in carrying out online EFL learning during the COVID-19 pandemic and reveal valid reasons behind. All interviews were recorded in audio format and transcribed to be analyzed further. Agreement was obtained from all participants before the research was carried out.

In lights of the research questions and recent online learning theories (Ally, 2008; Gonzalez \& Louis, 2018; Krish, 2008), the data were carefully reviewed and significant codes reflecting the practices of online EFL learning during the COVID-19 pandemic and its challenges were identified. Interview transcripts were read several times to obtain initial points of the practices of online EFL learning and its challenges. Data coding was done to exhibit classification and emerging trends. Repetitive and unimportant data were also deleted. Ultimately, appropriate extracts on the practices of online EFL 
REGISTER JOURNAL

Vol. 13, No. 1, (2020), pp.49-76

p-ISSN: 1979-8903; e-ISSN : 2503-040X

Website: http://journalregister.iainsalatiga.ac.id/index.php/register/

learning and its challenges were informed in results section. Some changes in terms of grammar were made to ensure the language efficacy of the extracts without altering the intention and meaning. To validate the data, data coding was done independently by both researchers, continued by several cycles of discussion to achieve an agreement about the results.

\section{RESULTS \& DISCUSSION}

This section conveys three key themes related to the practices of online EFL learning and the challenges encountered. It includes what applications and platforms used by the teachers, how they carry out online EFL learning, and what challenges they encounter along with the valid reasons. For each of the three themes, the most representative extracts from the participants' responses are picked out. The written reflections are labelled as 'WR' whereas the interviews are labelled as 'Int'.

\section{Applications and platforms used by the teachers}

The teachers use several applications and platforms which can be categorized into eight types. They are as follows: (1) learning management system; (2) chat and message; (3) video conference; (4) content maker; (5) assessment; (6) video streaming and sharing; (7) online learning provider; and (8) additional resource. The teachers do not employ game, artificial intelligence, virtual reality, and augmented reality.

The teachers employ Google Classroom and Schoology for managing their online learning in general. 
I decide to use Google Classroom because it does not need to be installed on their smartphones, so the students do not complain about spending their internet quota and requiring stable internet connection. The students only need to login by using their Gmail account and input the class code. So, it is easier and more accessible than other applications (T14, WR).

The first application which I use is Schoology. I utilize it to post materials related to Proverb and Riddle (T7, WR).

The teachers also employ WhatsApp to do many activities similarly to learning management system.

I use WhatsApp to share materials, give information about task or project, have discussion, provide question and answer session, and give personal feedback to students (T8, Int).

Zoom is chosen to carry out possible activities in tele-conference setting.

I utilize Zoom to explain materials orally like in face-to-face meeting, have oral discussion with students, and provide question and answer session (T4, WR).

Several content maker applications are also employed by the teachers.

They are Autodesk SketchBook, TEDEd, and FastStone Capture.

The second application which I use is Autodesk SketchBook. It is used to replace the function of whiteboard to present materials. We can create materials in written and drawing forms (T3, WR).

TEDEd and FastStone Capture are both video maker application. I utilize FastStone Capture to create a screen-casting video. In brief, I explain the materials orally by showing PowerPoint slides. Meanwhile, TEDEd is used to create a lesson video by editing available online videos (T9, Int).

Google Forms, Quizizz, and Kahoot are assessment applications which are employed by the teachers. They are used to create online quiz for students in the forms of multiple choices, essay, and true or false alternatives.

I utilize Kahoot to create quizzes in multiple choices of four options and true or false alternatives. I also use Google Forms to create quizzes in multiple choices of four options and essay forms. Kahoot needs more stable internet connection whereas Google Forms is more accessible in unstable internet connection. Google Forms also provides ease in score processing (T15, WR). 
REGISTER JOURNAL

Vol. 13, No. 1, (2020), pp.49-76

p-ISSN: 1979-8903; e-ISSN : 2503-040X

Website: http://journalregister.iainsalatiga.ac.id/index.php/register/

I employ Quizizz to create quizzes in multiple choices form (T7, WR).

YouTube is mostly used by the teachers as visual materials resource in the forms of video and animation.

I attach YouTube video links in my Google Classroom classes to provide my students with visual materials (T2, WR).

Ruangguru is one of online learning provider applications. The teacher takes some quiz items provided by this application.

I select some items of quizzes provided by Ruangguru which are relevant with the materials that I teach. I do some screenshots with my smartphones to capture some quiz items. I then share the selected quiz items through WhatsApp and ask my students to answer them (T3, Int).

The teachers also provide several websites as additional resources for their students. Those websites are such as http://en.childrenslibrary.org/, https://belajar.kemdikbud.go.id, and https://kelaspintar.id.

I ask my students to visit http://en.childrenslibrary.org/ and select a book which is available on the website. I give them time in one week to read the selected book. They are then required to write a review on the book they read. It is typically a reading assignment, particularly extensive reading assignment (T9, Int).

\section{The teachers' activities in carrying out online EFL learning}

There are teachers who carry out their online learning in synchronous mode and asynchronous mode. The synchronous mode means that the teachers carry out online learning at certain time in a week. In the other hand, the asynchronous mode means that the teachers carry out online learning in a range of longer period, one week for instance. So, the asynchronous mode is more flexible than the synchronous mode. However, majority of the teachers carry out their online learning in synchronous mode since it is their schools' policy. 
My school has set up the schedule for this online learning, so I must follow the rule of my institution (T7, WR).

My school does not give specific schedule to conduct the online learning. The most important thing is that each teacher must do teaching activities such as providing materials or assigning task or project for students every one week (T16, WR).

First, the teachers check the students' attendance. The teachers then adopt ready to use materials in the forms of PowerPoint slides, YouTube videos, and Word documents or create their own materials in the forms of videos, pictures, PowerPoint slides, Word documents, and PDF documents. The materials are uploaded by the teachers into learning management system such as Google Classroom and Schoology or shared through messaging application such as WhatsApp. After that, the teachers explain the materials by utilizing Zoom, for instance. The teachers' explanation can also be included in the materials such as in videos, Word documents, and PDF documents. The teachers then create online quizzes in the forms of multiple choices, essays, and true or false alternatives to assess the students' mastery of the subject. The teachers also assign the students to do some tasks and projects since some teachers apply project-based learning in their online learning. To gain deeper understanding and refine the students' lack of knowledge, the teachers carry out discussion along with the students. The teachers also provide question and answer session to engage the students and solve their learning problems. The teachers then give personal feedback on the students' works. The feedback is meant to help the students to progress in their learning personally. At the end, the teachers give score for every student's assessment.

I ask my students to indicate if they are present in the online learning as scheduled by mentioning their name and say that they are present in the comment of my attendance checking post in Google Classroom (T9, WR). 
REGISTER JOURNAL

Vol. 13, No. 1, (2020), pp.49-76

p-ISSN: 1979-8903; e-ISSN : 2503-040X

Website: http://journalregister.iainsalatiga.ac.id/index.php/register/

I download some ready to use materials related to my teaching topics in the forms of PowerPoint slides. I also download several relevant videos from YouTube to enrich the students' understanding on the topics. I then share those materials through WhatsApp (T8, Int).

I create some modules in PDF document format. I upload those modules to Google Drive. Then, I give the Google Drive links to my students so they can access the modules and read them as materials for their learning. I create these modules since I think that materials available on the students' textbook is hard to be learnt independently (T10, Int).

I upload my materials to Schoology as the learning management system. I upload the materials in many classes that I teach since I teach two different grades, namely grade tenth and eleventh (T7, WR).

I explain the materials through tele-conference facilitated by Zoom application. Here, I explain the materials orally by seeing my students' faces on my laptop screen (T16, WR).

I create materials in Word documents. I include my explanation which is usually delivered directly and orally into the materials. So, I write down the important points and briefs of the materials and my explanation into the same Word document (T13, WR).

I create online quizzes in the forms of multiple choices, essays, and true or false alternatives (T15, WR).

I assign my students a project to write a hortatory exposition text and an analytical exposition text with topics related to COVID-19 (T6, WR).

I carry out discussion on the generic structure of narrative text by posing some questions first to stimulate the discussion. The questions which I pose guide the students to critically understand the materials and initiate their questioning and reasoning ability. The students may answer my questions and ask other questions. So, there is knowledge exchange in this lively discussion (T9, Int).

I facilitate question and answer session through WhatsApp. This question and answer session takes place in WhatsApp group of each class that I teach. Students are allowed to ask questions related to their learning difficulties and lack of knowledge on the topics being taught (T7, Int). 
I always give personal feedback to my students' works through Google Classroom private comments feature and WhatsApp personal chat. I want my students to know what should be improved and how to improve it for better results. It leads the students to have good progress in their learning (T1, WR).

I always give score on my students' works since it must be reported on report books at the end of the semester. It also gives the students insights and reflections on how much they master the subject (T2, WR).

A series of activities carried out by the teachers is just like teaching activities in face-to-face class generally. The chronological order of the activities is similar to face-to-face class activities. The teachers just move the face-to-face class into online learning environment. They still do not consider much on the differences between face-to-face class and online learning. The teachers also do not maximize the use of technology in online learning. They do not employ game, artificial intelligence, augmented reality, and virtual reality. It seems that teachers' knowledge and skill on the use of technology in online learning need to be improved. The teachers should also be creative and innovative in providing activities for students in online learning environment. In short, moving face-to-face class into online learning environment is not enough. The teachers must be knowledgeable and skillful to teach through online learning. They must master the content (the language they teach), technology in online language learning, and pedagogy of foreign language learning.

\section{The challenges and valid reasons}

Many problems emerge in the online EFL learning carried out by the teachers. The problems come from the students, the teachers, and the students' parents. The valid reasons behind these problems are identified. The first problem is that some students do not have their own smartphone. It is usually caused by the financial condition of their family. 
REGISTER JOURNAL

Vol. 13, No. 1, (2020), pp.49-76

p-ISSN: 1979-8903; e-ISSN : 2503-040X

Website: http://journalregister.iainsalatiga.ac.id/index.php/register/

There are some students in my classes who do not own a smartphone. Their parents cannot afford a smartphone for their children due to their financial condition (T3, WR).

The second one is about unstable internet connection. The cellular signal and internet coverage still become a problem in remote and rural areas. In fact, some students live in remote, rural, and mountainous areas.

Some of my students complain about the unstable internet connection since they live in remote and mountainous areas (T5, WR).

The financial condition of the students and their family also generate another problem that is the inability to afford sufficient internet quota for online learning. They can only afford a small internet quota that is not enough to take part in the online learning comfortably.

Sometimes, my students do not have internet quota so they cannot access the internet and participate in the online learning. This problem happens because the income is not equally distributed to all inhabitants. Not all students come from a family of high or medium income which is able to afford decent livelihood (T8, Int).

Many students have low digital literacy. They find difficulties in operating the applications and platforms used for online learning. A logical reasoning behind this is that the students did not use to learn through online learning and interact with those applications and platforms.

At first, my students do not know how to copy paste and edit text in WhatsApp group to fill in the attendance list. Lots of my students also find difficulties in operating Google Classroom since they have never tried this application before. It makes me to create some tutorial videos on the use of Google Classroom to help them understand the way to operate it and how to copy paste and edit text in WhatsApp group (T10, Int).

Besides having low digital literacy, some students also have low literacy in general. They cannot understand the teacher's instruction well although it 
has been written clearly. It is usually because they do not carefully read the teacher's instruction and lazy to read the teacher's instruction. Sometimes, they skip the instruction if the words are too many for them.

I must repeatedly give the same information to my students simply because they are not careful enough to read the information. Their literacy is not good (T10, WR).

Some students are not punctual in attending the online learning as scheduled by the schools at certain time in a week. They are absent at the hours the online learning scheduled and ask the teachers about what has been taught and assigned in the afternoon. It happens since the students have misperceptions in mind.

In my students' opinion, learning from home is just like holidays. They go to sleep from morning to almost afternoon. They do not attend the online learning as scheduled in the morning until noon. They contact me in the afternoon and ask if there is any task or project given to them. Whereas, I do not serve them if it is not working hours (T11, WR).

Some students submit their works after the deadline. This can be caused by some reasons. Some students are lazy to do the task or project given by the teacher. It can be because their internet quota runs out. They may also experience unstable internet connection when submitting their works in the last minutes. It can happen for students who do not have their own smartphones so they must borrow their parents' or siblings' smartphones which are also used for online learning too. It may also be caused by their misperception that their works are not scored by the teacher.

Several students cannot meet the deadline of tasks. They submit their works lately since they do not own smartphones. They must borrow smartphones from their parents or siblings. Whereas, their siblings also require the smartphone to participate in online learning (T9, WR). Another emerging problem is students' different level of mastery on the subject which is generated from students' cognition and learning style. It has 
REGISTER JOURNAL

Vol. 13, No. 1, (2020), pp.49-76

p-ISSN: 1979-8903; e-ISSN : 2503-040X

Website: http://journalregister.iainsalatiga.ac.id/index.php/register/

been common that the students' mastery on the subject vary in a class, even in face-to-face class. It becomes a new challenge about how to teach students with low cognition and various learning style in online learning environment.

I find difficulties in delivering the materials to the students who need extra guidance in learning. It is due to their low cognition. It is rather difficult for me to teach them through online learning (T8, WR).

It is difficult to provide learning experience based on each student learning style. So, my students cannot achieve mastery on the subject optimally since they are not provided with learning experience which suits their learning style. It is hard and takes lots of time to prepare various learning experiences based on each student learning style in online learning environment (T7, Int).

Some students complain about the workload they have to do in online

learning. They suffer from lots of tasks and projects assigned to them with deadlines.

The students feel heavier burden of learning through online learning. It is because the students learn about 14 subjects through fully online learning and all of these subjects have assignments to be done by the students with deadlines (T7, Int).

Some students have low awareness on the online learning. They perceive that online learning is not important. This problem happens because the students have misperceptions about online learning. They assume that online learning is informal and just like holidays so they are too relaxed.

Sometimes, several students forget to participate in the online learning. They have low awareness on the online learning. They think that it is informal. It seems cliché to them since they have never experienced online learning before (T8, Int).

As the problems come from the students, the teachers also encounter challenges coming from themselves. At first, the teachers find difficulties in creating materials which are easy to learn in online learning setting since some 
teachers only use low technology applications due to the lack of facilities that their students suffer from. It is also due to the teachers' lack of experience and knowledge in carrying out the online learning.

I have difficulties in creating materials which are still in accordance with the core competence and the basic competence and easily understood by the students in independent learning since many students do not have adequate facilities to take part in an interactive online learning, for example, having their own smartphones with adequate specifications, stable internet connection, and adequate internet quota (T10, Int).

The teachers also find a problem in giving personal feedback to the students. It happens since the allotted time is still not enough and several students submit their works lately.

I cannot give personal feedback in real-time to each student work. The allotted time for online learning as scheduled by the school is not enough. Some students also submit their works lately, so I cannot give personal feedback to their works as soon as possible. The students also reply my feedback at different time. It is better if we can give personal feedback on the students' works in real-time (T1, WR).

The absence of adequate facilities for high technology integration becomes another problem in the online learning. It has been known that many students get troubled with unstable internet connection, inability to afford adequate internet quota, and lack of smartphones. Without adequate facilities, the teachers cannot carry out an interactive online learning. They can only give materials for independent learning at home, tasks or projects, and quizzes. Still, the teachers must choose the applications which do not require much internet quota and can still run in slow internet connection like Google Classroom, Google Forms, and WhatsApp.

I have not been able to carry out an interactive and engaging online learning since the facilities for online learning are still very minimal and far to carry out an interactive and engaging online learning. 
REGISTER JOURNAL

Vol. 13, No. 1, (2020), pp.49-76

p-ISSN: 1979-8903; e-ISSN : 2503-040X

Website: http://journalregister.iainsalatiga.ac.id/index.php/register/

Besides, the students' financial condition still cannot afford the required facilities (T3, Int).

Further, the teachers find difficulties in engaging low motivated and passive students in online learning setting. It is indicated by few students who get involved in discussion. Some students do not focus and even go to sleep when they participate in tele-conference. It happens due to the students' laziness, unstable internet connection, and low English language proficiency which demotivates them to participate in discussion and question and answer session conducted using English. The students' English language proficiency becomes another problem in this online learning. It is because the students do not use English in daily communication both inside and outside classroom.

My students tend to be passive and do not say many words when I give instruction or have discussion in English. They then ask about my instruction using Indonesian. They usually participate actively in discussion when we use Indonesian. They did not use to use English in discussion and other daily activities. They get confused in expressing their ideas and questions in English. They have low English language proficiency (T6, WR).

The teachers also complain about their lack of preparation and readiness in carrying out the online learning. It is because the online learning is not planned and prepared before. It happens suddenly to respond the COVID-19 pandemic in Indonesia.

I feel that I am not ready to move from face-to-face class to online learning since the online learning is carried out so suddenly in an emergency condition and is not prepared in advance (T7, Int).

Moreover, the teachers find difficulties in teaching moral value to their students. It is hard for them to educate their students morality through online learning since the teachers and the students are separated by far distance. 
It is hard to teach moral value to my students through online learning because of the distance so that I cannot provide exemplary attitude directly and intensively to my students (T7, Int).

In online learning, it is also hard to strengthen the emotional bond between the teacher and the students. It is due to the absence of physical touch and interaction in online learning.

The emotional bond between the teacher and the students is not very well facilitated since it is limited by far distance resulting in no faceto-face meeting and physical touch such as smiling and shaking hands which usually strengthen the emotional bond between the teacher and the students (T7, Int).

Communication and interaction between the teacher and the students are quite important in learning process. However, online learning still cannot facilitate communication and interaction as well as face-to-face class. It happens since the teacher and the students are limited by far distance. So, the communication and interaction between them are not optimized.

My students cannot reach me directly when they do not understand the materials or experience problems in learning. They find difficulties in having communication and interaction with me in online learning environment. I also reflect that online communication and interaction cannot replace face-to-face meeting in learning context (T5, WR).

Another problem is the absence of parents' care. Parents are hoped to monitor and maintain their children in participating in online learning. However, some parents do not take care of their children learning. They are busy with their works and business.

Many parents do not monitor and take care of their children's learning through online learning. It is because they are busy to work and their works cannot be done at home. They do not work from home since they work in informal sector (T12, WR).

The last problem is that the excessive use of smartphones and laptops can result in sore eyes. It is because the screen of smartphone and laptop emits radiations which are not good for our eyes and health. 
REGISTER JOURNAL

Vol. 13, No. 1, (2020), pp.49-76

p-ISSN: 1979-8903; e-ISSN : 2503-040X

Website: http://journalregister.iainsalatiga.ac.id/index.php/register/

I and my students experience fatigue and burnout when staring at our smartphone or laptop screens for a long time. It is due to the radiation effect from smartphones or laptops which are not good for our eyes if we use them for a long time (T8, Int).

The results show that the teachers carried out online EFL learning during the COVID-19 pandemic. The teachers employ many applicable applications and platforms based on their knowledge and the possibility of their students to access those applications and platforms due to the lack of the students' facilities. Those applications and platforms range from learning management system to additional resource. There are two ways in carrying out the online learning, namely synchronous and asynchronous mode. The majority of the teachers carry out the online learning in synchronous mode since their schools or institutions have given the rule and exact schedule to carry out the online learning. Moreover, the teachers carry out a series of activities to teach the students through online learning ranging from checking the students' attendance to giving score on the students' works. However, many challenges emerge from the students, the teachers, and the students' parents. The cause of each problem has been investigated and presented in the results section.

Many online learning applications quickly appear every day. Teachers are allowed to deliver materials to their students' smartphones. Teachers can employ some educational applications, references, and games to facilitate class activities (Son, 2018). Synchronous-based applications are useful to create contexts and facilitate teachers and students to interact with each other in realtime. Moreover, asynchronous-based applications can be utilized for low technology use through discussions and written responses. A thorough and 
balanced mix of activities can attract students to online learning (Plaisance, 2018).

Teachers should provide simple, obvious, and proper instructions about what to do, how to do it, and where students must submit their works. Activities should be determined by considering objectives and arranged sequentially in tasks reflecting real-life situations to gain students' interest and make them motivated (Gonzalez \& Louis, 2018). Teachers must be able to recognize disengagement, present meaningful activity, provide question and answer session, and offer ice-breaking activity to maintain students' engagement. Sufficient challenge, resource, and feedback must also be provided for students (Green, 2016).

Challenges include relating pedagogies with technologies, designing interactive activities, enhancing formal learning, gaining students' support, and dealing with problems in the use of technology (Son, 2018). Other difficulties in fully online learning are meeting scheduled participation and regular learning, maintaining persistent engagement, becoming a self-directed learner with high motivation, and socializing (Sun, 2014). Problems also come from the inability to afford smartphone and internet quota for students as well as the unstable internet connection. Good pedagogy will be nonsense if there are problems in technology access (Burston, 2014; Cakrawati, 2017).

Preparing online learning spend more time than preparing face-to-face class (Krish, 2008). Online learning needs a bigger investment than face-toface class to make it properly designed and implemented (Green, 2016). It must be skillfully carried out to avoid friction and disengagement since online students can feel like in isolation and disconnection (Plaisance, 2018). It also requires more responsible and autonomous students. They have to be selfdirected learners with high motivation who spend time effectively to prepare, 
REGISTER JOURNAL

Vol. 13, No. 1, (2020), pp.49-76

p-ISSN: 1979-8903; e-ISSN : 2503-040X

Website: http://journalregister.iainsalatiga.ac.id/index.php/register/

maintain, manage, and reflect on their learning and participation (Gonzalez \& Louis, 2018). Moreover, student-teacher and student-material interactions have significant and positive effects on students' satisfaction. Thus, teachers need to scaffold interactions of student-teacher and student-material to enhance students' learning (Chin-Hsi Lin, Zheng, \& Zhang, 2017).

The challenges encountered must inspire teachers to be reflective, open, creative, and adaptive to dynamic changes. It reminds teachers to keep exploring technology for enhancing foreign language learning. Teachers need to identify applications and use them based on the objectives. To select and utilize suitable applications timely, teachers need practical preparation and learning on recognizing applications, organizing activities, maintaining students' engagement, and evaluating students' learning. Teachers are encouraged to have active participation in professional development opportunities to develop their competency on technology integration in language teaching (Son, 2018). Training should be given to make them wellprepared to carry out online learning in emergency incidents (Moorhouse, 2020).

\section{CONCLUSION}

The present research gives contributions to the literature on online language learning in EFL context from teachers' perspective. EFL teachers have carried out online learning through a series of activities ranging from checking the students' attendance to giving score on the students' works synchronously or asynchronously depending on each school policy due to the 
COVID-19 pandemic. Various applications and platforms ranging from learning management system to additional resource are employed to carry out the online learning. However, many problems emerge from the students, the teachers, and the students' parents. As results, the online learning does not run well since it lacks of preparation and planning.

Planning and preparation should inevitably be done for better online learning in the future since online learning requires more time than face-toface class to be well-prepared and ready. The teachers must be trained and prepared with sufficient knowledge and skill to maximize their practices in carrying out the online learning. The students have to be familiarized with online learning to enhance their digital literacy and refine their misperceptions about online learning. The students' parents must also be notified to monitor and maintain their children participation and engagement in the online learning. However, the students' lack of facilities on smartphones, internet quota, and stable internet connection are still critical due to the financial condition of the students' families.

The future teacher education and training must include the integration of technology in language learning, technology enhanced language learning, information and communication technology in language learning, and online language learning courses in their curriculum since the needs of technology integration in language learning is inevitable. More researches are encouraged to investigate the practices of online EFL learning in low technology context and the needs of teacher professional development on technology integration in language learning. As suggested by Moorhouse (2020), extensive researches which explore the switch of face-to-face class into online learning are also worth to carry out. 
REGISTER JOURNAL

Vol. 13, No. 1, (2020), pp.49-76

p-ISSN: 1979-8903; e-ISSN : 2503-040X

Website: http://journalregister.iainsalatiga.ac.id/index.php/register/

\section{REFERENCES}

Ally, M. (2008). Foundations of Educational Theory for Online Learning. In T. Anderson (Ed.), The Theory and Practice of Online Learning (2nd ed., pp. 15-44). Edmonton: AU Press.

Blake, R. J. (2011). Current Trends in Online Language Learning. Annual Review of Applied Linguistics, 31, 19-35. https://doi.org/10.1017/S026719051100002X

BNPB. (2020). Keputusan Kepala Badan Nasional Penanggulangan Bencana Nomor 13.A Tahun 2020 (pp. 1-2). pp. 1-2. Retrieved from https://www.docdroid.net/file/download/ZQfEj4d/sk-ka-no-13-a-tahun2020.pdf

Burston, J. (2014). MALL: The Pedagogical Challenges. Computer Assisted Language Learning, 27(4), 344-357. https://doi.org/10.1080/09588221.2014.914539

Cakrawati, L. M. (2017). Students' Perceptions on the Use of Online Learning Platforms in EFL Classroom. English Language Teaching and Technology Journal, 1(1), 22-30.

Cao, W., Fang, Z., Hou, G., Han, M., Xu, X., Dong, J., \& Zheng, J. (2020). The Psychological Impact of the COVID-19 Epidemic on College Students in China. Psychiatry Research, 287, 1-5. https://doi.org/10.1016/j.psychres.2020.112934

Gonzalez, D., \& Louis, R. St. (2018). Online Learning. In J. I. Liontas (Ed.),

The TESOL Encyclopedia of English Language Teaching (1st ed.). https://doi.org/10.1002/9781118784235.eelt0423 
Green, P. (2016). How to Succeed with Online Learning. In N. Rushby \& D. W. Surry (Eds.), The Wiley Handbook of Learning Technology (1st ed., pp. 261-286). https://doi.org/10.1002/9781118736494.ch15

Jayanti, F. G., \& Norahmi, M. (2014). EFL: Revisiting ELT Practices in Indonesia. Journal on English as a Foreign Language, 4(1), 5-14. https://doi.org/10.23971/jefl.v4i1.70

Kam, H. W. (2002). English Language Teaching in East Asia Today: An Overview. Asia Pacific Journal of Education, 22(2), 1-22. https://doi.org/10.1080/0218879020220203

Krish, P. (2008). Language Learning in the Virtual World: Instructors' Voices. International Journal of Pedagogies and Learning, 4(4), 113-129. https://doi.org/10.5172/ijpl.4.4.113

Lauder, A. (2008). The Status and Function of English in Indonesia: A Review of Key Factors. Makara Human Behaviour Studies in Asia, 12(1), 9-20. https://doi.org/10.7454/mssh.v12i1.128

Lie, A. (2007). Education Policy and EFL Curriculum in Indonesia: Between the Commitment to Competence and the Quest for Higher Test Scores. $\begin{array}{lll}\text { TEFLIN Journal, } & \text { 18(1), }\end{array}$ https://doi.org/10.15639/teflinjournal.v18i1/1-15

Lin, Chin-Hsi, Zheng, B., \& Zhang, Y. (2017). Interactions and Learning Outcomes in Online Language Courses. British Journal of Educational Technology, 48(3), 730-748. https://doi.org/10.1111/bjet.12457

Lin, Chin-Hsi, \& Warschauer, M. (2015). Online Foreign Language Education: What Are the Proficiency Outcomes? The Modern Language Journal, 99(2), 394-397. https://doi.org/10.1111/modl.12234_1

Marcellino, M. (2005). Competency-Based Language Instruction in Speaking Classes: Its Theory and Implementation in Indonesian Contexts. 
REGISTER JOURNAL

Vol. 13, No. 1, (2020), pp.49-76

p-ISSN: 1979-8903; e-ISSN : 2503-040X

Website: http://journalregister.iainsalatiga.ac.id/index.php/register/

Indonesian Journal of English Language Teaching, 1(1), 33-44. https://doi.org/10.25170\%2Fijelt.v1i1.95

McAleer, M. (2020). Prevention Is Better Than the Cure: Risk Management of COVID-19. Journal of Risk and Financial Management, 13(3). https://doi.org/10.3390/jrfm13030046

Mendikbud. (2020a). Surat Edaran Mendikbud: Pelaksanaan Kebijakan Pendidikan dalam Masa Darurat Penyebaran Corona Virus Disease (COVID-19). Retrieved from http://kemdikbud.go.id/main/files/download/51e9b72ef92c6d8

Mendikbud. (2020b). Surat Edaran Mendikbud: Pembelajaran secara Daring dan Bekerja dari Rumah dalam Rangka Pencegahan Penyebaran Corona Virus Disease (COVID-19). Retrieved from http://kemdikbud.go.id/main/files/download/c5d9f0ec9ff40c6

Moorhouse, B. L. (2020). Adaptations to a Face-to-Face Initial Teacher Education Course 'Forced' Online due to the COVID-19 Pandemic. Journal of Education for Teaching. https://doi.org/10.1080/02607476.2020.1755205

Plaisance, M. (2018). Online Course Delivery. In J. I. Liontas (Ed.), The TESOL Encyclopedia of English Language Teaching (1st ed.). https://doi.org/10.1002/9781118784235.eelt0129

Smith, B. D. (1991). English in Indonesia. English Today, 7(2), 39-43. https://doi.org/10.1017/S0266078400005526

Son, J. (2018). Technology in English as a Foreign Language (EFL) Teaching. In J. I. Liontas (Ed.), The TESOL Encyclopedia of English Language 
Teaching (1st ed.). https://doi.org/10.1002/9781118784235.eelt0448

Sun, S. Y. H. (2014). Learner Perspectives on Fully Online Language Learning. Distance Education, 35(1), 18-42. https://doi.org/10.1080/01587919.2014.891428

Velavan, T. P., \& Meyer, C. G. (2020). The COVID-19 Epidemic. Tropical Medicine and International Health, 25(3), 278-280. https://doi.org/10.1111/tmi.13383

White, C. (2008). Innovation and Identity in Distance Language Learning and Teaching. Innovation in Language Learning and Teaching, 1(1), 97-110. https://doi.org/10.2167/illt45.0

WHO. (2020). Coronavirus Disease 2019 (COVID-19) Situation Report - 72. Retrieved from https://www.who.int/docs/defaultsource/coronaviruse/situation-reports/20200401-sitrep-72-covid19.pdf?sfvrsn=3dd8971b_2

Wulyani, A. N., Elgort, I., \& Coxhead, A. (2019). Exploring EFL Teachers' English Language Proficiency: Lessons from Indonesia. Indonesian Journal of Applied Linguistics, 9(2), 263-274. https://doi.org/10.17509/ijal.v9i2.20217

Yusny, R. (2013). ELT in Indonesian Context: Issues and Challenges. Englisia Journal, 1(1), 81-98. https://doi.org/10.22373/ej.v1i1.140

Zein, S. (2018). English, Multilingualism and Globalisation in Indonesia: A Love Triangle: Why Indonesia Should Move towards Multilingual Education. $\quad$ English $\quad$ Today, 35(1), 48-53. https://doi.org/10.1017/S026607841800010X 